This is a self-archived version of an original article. This version may differ from the original in pagination and typographic details.

Author(s): Truong, Khai-Nghi; Rautiainen, J. Mikko; Rissanen, Kari; Puttreddy, Rakesh

Title: ${ }^{\text {The }} \mathrm{C}-\mathrm{I}^{-} \mathrm{O}-\mathrm{N}^{+}$Halogen Bonds with Tetraiodoethylene and Aromatic N-oxides

Year: 2020

Version: Accepted version (Final draft)

Copyright: (c) 2020 American Chemical society

Rights: In Copyright

Rights url: http://rightsstatements.org/page/lnC/1.0/?language=en

Please cite the original version:

Truong, K.-N., Rautiainen, J. M., Rissanen, K., \& Puttreddy, R. (2020). The C-I-O- $\mathrm{N}^{+}$Halogen Bonds with Tetraiodoethylene and Aromatic N-oxides. Crystal Growth and Design, 20(8), 53305337. https://doi.org/10.1021/acs.cgd.0c00560 


\section{CRYSTAL GROWTH हुDESIGN}

Subscriber access provided by JYVASKYLAN UNIV

\section{Article}

\section{The C-I\#\#\#\#-N\# Halogen Bonds with Tetraiodoethylene and Aromatic N-oxides}

Khai-Nghi Truong, J. Mikko Rautiainen, Kari Rissanen, and Rakesh Puttreddy

Cryst. Growth Des., Just Accepted Manuscript • DOI: 10.1021/acs.cgd.0c00560 • Publication Date (Web): 18 Jun 2020

Downloaded from pubs.acs.org on June 22, 2020

\section{Just Accepted}

"Just Accepted" manuscripts have been peer-reviewed and accepted for publication. They are posted online prior to technical editing, formatting for publication and author proofing. The American Chemical Society provides "Just Accepted" as a service to the research community to expedite the dissemination of scientific material as soon as possible after acceptance. "Just Accepted" manuscripts appear in full in PDF format accompanied by an HTML abstract. "Just Accepted" manuscripts have been fully peer reviewed, but should not be considered the official version of record. They are citable by the Digital Object Identifier (DOI®). "Just Accepted" is an optional service offered to authors. Therefore, the "Just Accepted" Web site may not include all articles that will be published in the journal. After a manuscript is technically edited and formatted, it will be removed from the "Just Accepted" Web site and published as an ASAP article. Note that technical editing may introduce minor changes to the manuscript text and/or graphics which could affect content, and all legal disclaimers and ethical guidelines that apply to the journal pertain. ACS cannot be held responsible for errors or consequences arising from the use of information contained in these "Just Accepted" manuscripts. 


\title{
The C-I $\cdot{ }^{-} \mathrm{O}-\mathrm{N}^{+}$Halogen Bonds with
}

\section{Tetraiodoethylene and Aromatic $N$-oxides}

\author{
Khai-Nghi Truong ${ }^{1}$, J. Mikko Rautiainen ${ }^{1}$, Kari Rissanen ${ }^{1}$, and \\ Rakesh Puttreddy $1,2, *$ \\ ${ }^{1}$ Department of Chemistry, University of Jyvaskyla, P. O. Box 35, Jyväskylä, FI-40014, \\ Finland. \\ ${ }^{2}$ Faculty of Engineering and Natural Sciences, Tampere University, P. O. Box 541, \\ Tampere, FI-33101, Finland. \\ *Correspondence: rakesh.puttreddy@tuni.fi
}

\begin{abstract}
The nature of $\mathrm{C}-\mathrm{I} \cdot \cdots^{-} \mathrm{O}-\mathrm{N}^{+}$interactions, first of its kind, between non-fluorinated tetraiodoethylene $\mathrm{XB}$-donor and pyridine $\mathrm{N}$-oxides (PyNO) are studied by single-crystal X-ray diffraction (SCXRD) and Density Functional Theory (DFT) calculations. Despite the non-fluorinated nature of the $\mathrm{C}_{2} \mathrm{I}_{4}$, the $\mathrm{I} \cdots \mathrm{O}$ halogen bond distances are similar to well-known perfluorohaloalkane/-arene donor-PyNO analogues. With $\mathrm{C}_{2} \mathrm{I}_{4}$, oxygens of the $N$-oxides adopt exclusively $\mu_{2}$-XB-coordination in contrast to the versatile bonding modes observed with perfluorinated XB-donors. The $\mathrm{C}_{2} \mathrm{I}_{4}$ as the $\mathrm{XB}$ donor forms with PyNO's one-dimensional chain polymer structures in which the $\mathrm{C}_{2} \mathrm{I}_{4} \cdots(\mu \text {-PyNO })_{2} \cdots \mathrm{C}_{2} \mathrm{I}_{4}$ segments manifesting two bonding motifs, namely, side-by-side (vicinal di-iodo) and head-to-head (geminal di-iodo), due to the nearly symmetric square planar structure of the $\mathrm{C}_{2} \mathrm{I}_{4}$. While the attractive nature between I- and O-atoms is mainly electrostatic, the narrow range of $\mathrm{C} \cdot \cdots \mathrm{O}$ bond parameters demonstrate that the $\pi$-bond between four iodine atoms also plays
\end{abstract}


an important role in enhancing the $\sigma$-hole strength. DFT-based monodentate XB interaction energies, $\Delta \mathrm{E}_{\mathrm{int}}$, in thirteen $1: 1 \mathrm{XB}$ complexes vary between $31.9-46.5 \mathrm{~kJ} \mathrm{~mol}^{-1}$, the strongest remarkably exceeding the value reported for $\mathrm{I}-\mathrm{I} \cdots{ }^{-} \mathrm{O}-\mathrm{N}^{+}=42.0 \mathrm{~kJ} \mathrm{~mol}^{-1}$. In case of $\mathrm{C}_{2} \mathrm{I}_{4} \cdot$ (pyridine $N$-oxide) [31.9 $\mathrm{kJ} \mathrm{mol}^{-1}$, the monodentate $\mathrm{XB}$ energy is on a par with perfluorinated donor complexes, namely, $\mathrm{CF}_{3} \mathrm{I} \cdot\left(\right.$ pyridine $N$-oxide) $\left[31.1 \mathrm{~kJ} \mathrm{~mol}^{-1}\right]$ and $\mathrm{C}_{6} \mathrm{~F}_{5} \mathrm{I} \cdot\left(\right.$ pyridine $N$-oxide) $\left[32.3 \mathrm{~kJ} \mathrm{~mol}^{-1}\right]$.

KEYWORDS: Halogen bond; $N$-oxide; pyridine; pyridine $N$-oxide; tetraiodoethylene.

\section{INTRODUCTION}

Halogen bonding, an electrostatic attractive interaction between electropositive region in a halogen and a nucleophile, ${ }^{1}$ is a topic that has been extensively exploited and developed for applications in supramolecular chemistry, and these include crystal engineering, ${ }^{2}$ anion recognition, ${ }^{3}$ and catalysis. ${ }^{4}$ The high directional nature of halogen bond (XB), conceptionally similar to hydrogen bond (HB), makes $\mathrm{XB}$ an important non-covalent interaction. The notable differences in bond angles between HB and XB arise due to the smaller size of $\mathrm{H}$-atom. Unlike in the H-atom, the electron-deficient region in covalently bonded halogens, termed as $\sigma$-hole, is encompassed orthogonally by a negative region generating directional preference for halogen bonding. ${ }^{5,6}$ The size of the $\sigma$-hole of a covalently bound halogen $(\mathrm{D}-\mathrm{X}, \mathrm{D}=$ non-hydrogen atom, $\mathrm{X}=$ halogen $)$ increases with the atomic radius, $\mathrm{F}<<\mathrm{Cl}<\mathrm{Br}<\mathrm{I}$, as a consequence, fluorine lacks appreciable $\sigma$-hole to function as an XB-donor. ${ }^{7}$ Whilst the iodine, not only has larger $\sigma$-hole but also is easily polarized which facilitates tuning of the electropositive region for different $\sigma$-hole strengths. ${ }^{8}$ For example, the rational substitution of aromatic hydrogens by fluorine atoms in iodobenzene increases $\sigma$-hole of the iodine atom as evidenced by the $\mathrm{V}_{\mathrm{s} \text {,max }}$ values on iodine viz. iodobenzene $\left(17.3 \mathrm{~kJ} \mathrm{~mol}^{-1}\right)$, 2,6-difluoroiodobenzene $\left(25.5 \mathrm{~kJ} \mathrm{~mol}^{-1}\right)$, 
3,5-difluoroiodobenzene $\left(26.1 \mathrm{~kJ} \mathrm{~mol}^{-1}\right)$, and 2,3,4,5,6-pentafluoroiodobenzene $(35.9 \mathrm{~kJ}$ $\left.\mathrm{mol}^{-1}\right) .{ }^{9}$ The XB binding affinity can be tuned not only by varying the $\sigma$-hole strength but also by increasing the electron-donating ability of acceptor molecules. ${ }^{10}$ Tuning of the XB acceptor and donor properties guided by theoretical studies have so far been utilized in case of $N$-heterocycles and iodoperfluorocarbons allowing the engineering of novel two- and three-dimensional structures and materials that take advantage of the different structural topologies. ${ }^{11,12}$

Halogen bonding between carbon-bonded halogens $(\mathrm{C}-\mathrm{X})$ and nitrogen-based Lewis bases has thus far received most of the attention in research while XBs of other Lewis bases, such as oxygen and sulfur, have been less explored. ${ }^{13}$ There is however no reason to overlook the exploration of $\mathrm{C}-\mathrm{X} \cdots \mathrm{A}(\mathrm{A}=\mathrm{O}, \mathrm{S})$ halogen bonds. Knowledge of the interaction strengths and bonding geometries between different interacting partners can be seen as important tools for the XB community in designing new halogen bonded systems. Especially understanding of the $\mathrm{C}-\mathrm{X} \cdots \mathrm{O}$ XBs can help to engineer new halogenated drug molecules with improved affinities and selectivity to protein-ligand complexes. ${ }^{14}$ This results from the peptide bonds $\left(-\mathrm{CO}-\mathrm{NH}^{-}\right)$that connect the amino acid building blocks of proteins forming long chains and binding pockets facilitating $\mathrm{C}-\mathrm{X} \cdot \cdots \mathrm{O}=\mathrm{C} \mathrm{XB}$ interactions. $^{14}$

$\mathrm{N}$-oxide oxygens and aromatic $\mathrm{N}$-oxides, in particular, provide excellent model systems for exploring the $\mathrm{C}-\mathrm{X} \cdots \mathrm{O} \mathrm{XB}$ interactions. The presence of three electron pairs on the $N$-oxide oxygen allows for mono-, bi-, and tridentate coordination modes and easy tunability of the acceptor properties. ${ }^{15} \mathrm{We}$ have previously reported $\mathrm{C}-\mathrm{I} \cdot{ }^{-} \mathrm{O}-\mathrm{N}^{+} \mathrm{XBs}$ between methyl-substituted pyridine $N$-oxides and 1, $\omega$-diiodoperfluoroalkanes. ${ }^{16}$ The work demonstrated how the XB strengths in crystal structure could be varied by (i) increasing 
nucleophilicity of the acceptor by installing electron-donating methyl groups, and (ii) adding electron-withdrawing fluorines in the surroundings of the donor halogen.

A Cambridge Structural Database $(\mathrm{CSD})^{17}$ search for a non-fluorinated molecule namely tetraiodoethylene $\left(\mathrm{C}_{2} \mathrm{I}_{4}\right)$ functioning as an $\mathrm{XB}$ donor revealed only 53 hits, against acceptor atoms featuring halides, ${ }^{18-22}$ nitrogens, ${ }^{23-29}$ sulphurs, ${ }^{30,31}$ seleniums, ${ }^{32,33}$ and metal-bound halogens. ${ }^{34}$ To our surprise, there was only one report with O-atom functioning as acceptor, ${ }^{35}$ suggesting that the $\mathrm{I} \cdots \mathrm{O}$ XB-bonding nature and interaction strengths are less known compared to perfluorinated $\mathrm{XB}$ donor molecules, e.g. 1, $\omega$-diiodoperfluoroalkanes and 1,n-haloperfluoroaromatics. ${ }^{13,36}$ Our interest to explore O-atom based XBs led to the investigation of $\mathrm{C}-\mathrm{I} \cdot \cdots^{-} \mathrm{O}-\mathrm{N}^{+} \mathrm{XBs}$ between non-fluorinated $\mathrm{C}_{2} \mathrm{I}_{4}$ and thirteen PyNOs, containing methyl-, and phenyl-substituents at ortho-, meta- and para-positions to the $N$-oxide group [see Figure 1]. Analyses in the current investigation relied primarily on two techniques: (a) single-crystal X-ray diffraction analysis, and (b) computational studies.

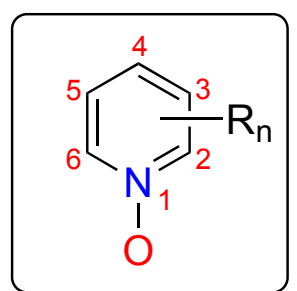

(8) $\mathrm{R}_{2}=-\mathrm{Ph}$

(9) $\mathrm{R}_{3}=-\mathrm{Ph}$

(10) $R_{4}=-P h$

(11) $R_{2}, R_{6}=-P h$

(12) $R_{2}, R_{4}=-P h$

(13) $R_{2}, R_{4}, R_{6}=-P h$

(1) $\mathrm{R}_{1}-\mathrm{R}_{6}=-\mathrm{H}$

(2) $\mathrm{R}_{2}=-\mathrm{CH}_{3}$

(3) $\mathrm{R}_{3}=-\mathrm{CH}_{3}$

(4) $\mathrm{R}_{4}=-\mathrm{CH}_{3}$

(5) $\mathrm{R}_{2}, \mathrm{R}_{6}=-\mathrm{CH}_{3}$

(6) $\mathrm{R}_{2}, \mathrm{R}_{4}=-\mathrm{CH}_{3}$

(7) $\mathrm{R}_{2}, \mathrm{R}_{4}, \mathrm{R}_{6}=-\mathrm{CH}_{3}$<smiles>IC(I)=C(I)I</smiles>

$\mathrm{C}_{2} \mathrm{I}_{4}$

Figure 1. List of XB acceptors, $N$-oxides (1-13), and XB donor tetraiodoethylene $\left(\mathrm{C}_{2} \mathrm{I}_{4}\right)$. 


\section{RESULTS AND DISCUSSIONS}

Ten out of thirteen acceptor-donor combinations yielded single crystals suitable for X-ray diffraction analysis, namely, $\mathbf{1} \cdot \mathrm{C}_{2} \mathrm{I}_{4}-\mathbf{1 0} \cdot \mathrm{C}_{2} \mathrm{I}_{4}$, while $\mathbf{1 1} \cdot \mathrm{C}_{2} \mathrm{I}_{4}-\mathbf{1 3} \cdot \mathrm{C}_{2} \mathrm{I}_{4}$ were obtained as gel-type materials. The distances and bond angles associated with $\mathrm{I} \cdots \mathrm{O}$ interactions, as well as $\mathrm{R}_{\mathrm{XB}}$ values, which are used to demonstrate that $\mathrm{XB}$ contacts are less than the sum of the van der Waals radii of I- and O-atoms, are listed in Table 1. In each XB-complex, all the four iodine atoms of $\mathrm{C}_{2} \mathrm{I}_{4}$ participate in X-bonding with $\mathrm{I} \cdots \mathrm{O}$ distances ranging from $2.741(6)$ to $3.045(7) \AA$, that are comparable to those reported between perfluorinated XB-donors and $N$-oxide acceptors in the literature (see Supporting Information, Table S1 and S2) and mostly shorter than the I...O distance 3.004(7) $\AA$ found for $\mathrm{C}_{2} \mathrm{I}_{4} \cdot\left(1,4\right.$-dioxane) system. ${ }^{35}$ The $N$-oxide oxygen in $\mathbf{1} \cdot \mathrm{C}_{2} \mathrm{I}_{4}-\mathbf{1 0} \cdot \mathrm{C}_{2} \mathrm{I}_{4}$ has stringent $\mu_{2}$-XB-coordination mode contrary to its varying denticities, viz mono-, bi-, and tridentate, observed with perfluorinated XB-donors. ${ }^{37-42}$ The $\mathrm{C}_{2} \mathrm{I}_{4}$ donor is found to exhibit two kinds of bonding modes that are abbreviated as side-by-side (vicinal, vic) and head-to-head (geminal, gem) as illustrated in Figure 2. The former mode is defined when a $\mu_{2}$-XB modes for $\mathrm{N}$-oxides are established between iodine substituents at $\mathrm{C} 1 / \mathrm{C} 1{ }^{\prime}$-positions and $\mathrm{C} 2 / \mathrm{C} 2$ '-positions, and the latter, when a $\mu_{2}-\mathrm{XB}$ modes are formed between $\mathrm{C} 1 / \mathrm{C} 2$ and $\mathrm{C}^{\prime} / \mathrm{C} 2^{\prime}$ substituents. Curiously, the $\mathrm{C}_{2} \mathrm{I}_{4}$ is disordered in 5 structures, namely both 2,6-dimethyl-substituted $\left(5 \cdot \mathrm{C}_{2} \mathrm{I}_{4}\right.$ and $\left.7 \cdot \mathrm{C}_{2} \mathrm{I}_{4}\right)$ and all phenyl-PyNOs XB complexes, displaying both vic- and gem-bonding modes, in which gem is the slightly favoured mode. Whilst, the other five XB complexes with ordered $\mathrm{C}_{2} \mathrm{I}_{4}$ exhibit solely the vic-bonding mode. This preferential behaviour might have occurred due to the (i) $C_{2} I_{4}$ ability to form two $D_{2 h}$ symmetry structures at orthogonal orientations, ${ }^{43}$ and (ii) steric constraints demanded by substituents on PyNOs in the molecular packing. 


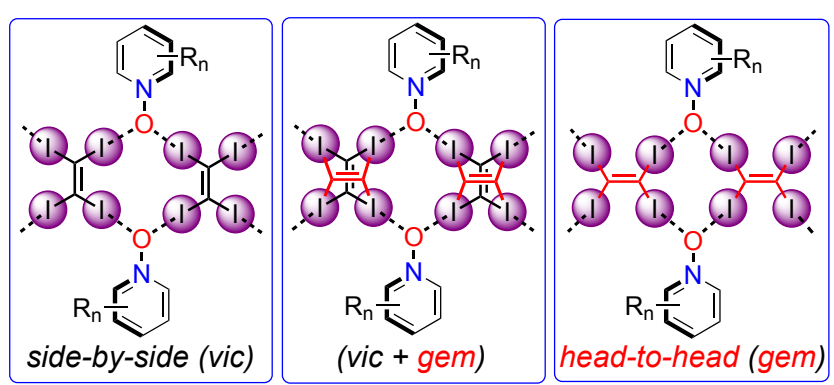

Figure 2. $\mathrm{C}_{2} \mathrm{I}_{4}$ bonding modes in 1-D polymeric structures.

The asymmetric units of methyl-substituted XB complexes, $\mathbf{1} \cdot \mathrm{C}_{2} \mathrm{I}_{4}-\mathbf{5} \cdot \mathrm{C}_{2} \mathrm{I}_{4}$, and $\mathbf{7} \cdot \mathrm{C}_{2} \mathrm{I}_{4}$, all have 1:0.5 $N$-oxide:donor ratio while $6 \cdot \mathrm{C}_{2} \mathrm{I}_{4}$ crystallized in a 2:1.5 ratio. The complexes are 1-D polymers and have similar packing structures with $N$-oxide aromatics "orthogonal" to planes of $\mathrm{C}_{2} \mathrm{I}_{4}$ molecules [see Figure 3, 4, S1, and S2]. This alignment allows the acceptor molecules from the adjacent 1-D polymers to stabilize the structure by $\mathrm{C}-\mathrm{H}^{\cdots}{ }^{-} \mathrm{O}-$ $\mathrm{N}^{+}$interactions $\left[c a . d\left(\mathrm{O}^{-} \cdots \mathrm{H}\right)=2.340-2.642 \AA, \angle\left(\mathrm{O}^{-} \cdots \mathrm{H}-\mathrm{C}\right)=147.1-168.4^{\circ}\right]$ in addition to $\mathrm{C}-\mathrm{I} \cdots{ }^{-} \mathrm{O}-\mathrm{N}^{+}$XBs. The $\mathrm{C}-\mathrm{H} \cdot \cdots^{-} \mathrm{O}-\mathrm{N}^{+}$hydrogen bond interactions in $\mathrm{N}$-oxide structures reinforces network formations and have been regarded as important contacts in crystal engineering studies. ${ }^{44,45}$ The $\mu_{3^{-}}$(one HB and two XBs) tridentate modes were not observed in $\mathbf{5} \cdot \mathrm{C}_{2} \mathrm{I}_{4}$ and $\mathbf{7} \cdot \mathrm{C}_{2} \mathrm{I}_{4}$ due to the absence of ortho-C-H protons [e.g. see Figure $4(\mathrm{a})$ and $\mathrm{S} 2$ ]. Instead, the $(\mathrm{C}-\mathrm{H}) \cdots \mathrm{C}$ contacts between para-C$-\mathrm{H}$ and ortho-methyl carbon arise in the packings of $5 \cdot \mathrm{C}_{2} \mathrm{I}_{4}$ and $7 \cdot \mathrm{C}_{2} \mathrm{I}_{4}$, hinting a potential new $\mathrm{HB}$ synthon for crystal engineering applications. In $6 \cdot \mathrm{C}_{2} \mathrm{I}_{4}$, the $N$-oxide is $\mu_{3}$ - (one $\mathrm{HB}$ and two XBs) coordinating, and unlike other methyl-substituted complexes, an intricate packing behaviour is observed as shown in Figure 4(b). The differences in molecular packing arise from the halogen $\cdots$ halogen interactions between $\mathrm{C}_{2} \mathrm{I}_{4}$ donors. Of the two crystallographically independent $\mathrm{C}_{2} \mathrm{I}_{4}$ molecules, only the symmetry-related full occupancy $\mathrm{C}_{2} \mathrm{I}_{4}$ donors interact with each other for $\mathrm{C}-\mathrm{I} \cdots \mathrm{I}^{\prime}-\mathrm{C}$ interactions at distances of $3.752 \AA\left[\angle\left(\mathrm{C}-\mathrm{I} \cdots \mathrm{I}^{\prime}\right)=169.3^{\circ}\right]$ and $3.884 \AA[\angle(\mathrm{C}-$ $\left.\mathrm{I}^{\prime} \cdot \mathrm{I}^{\prime}\right)=162.8^{\circ}, \mathrm{I}^{\prime}=$ XB-acceptor $]$, respectively. 


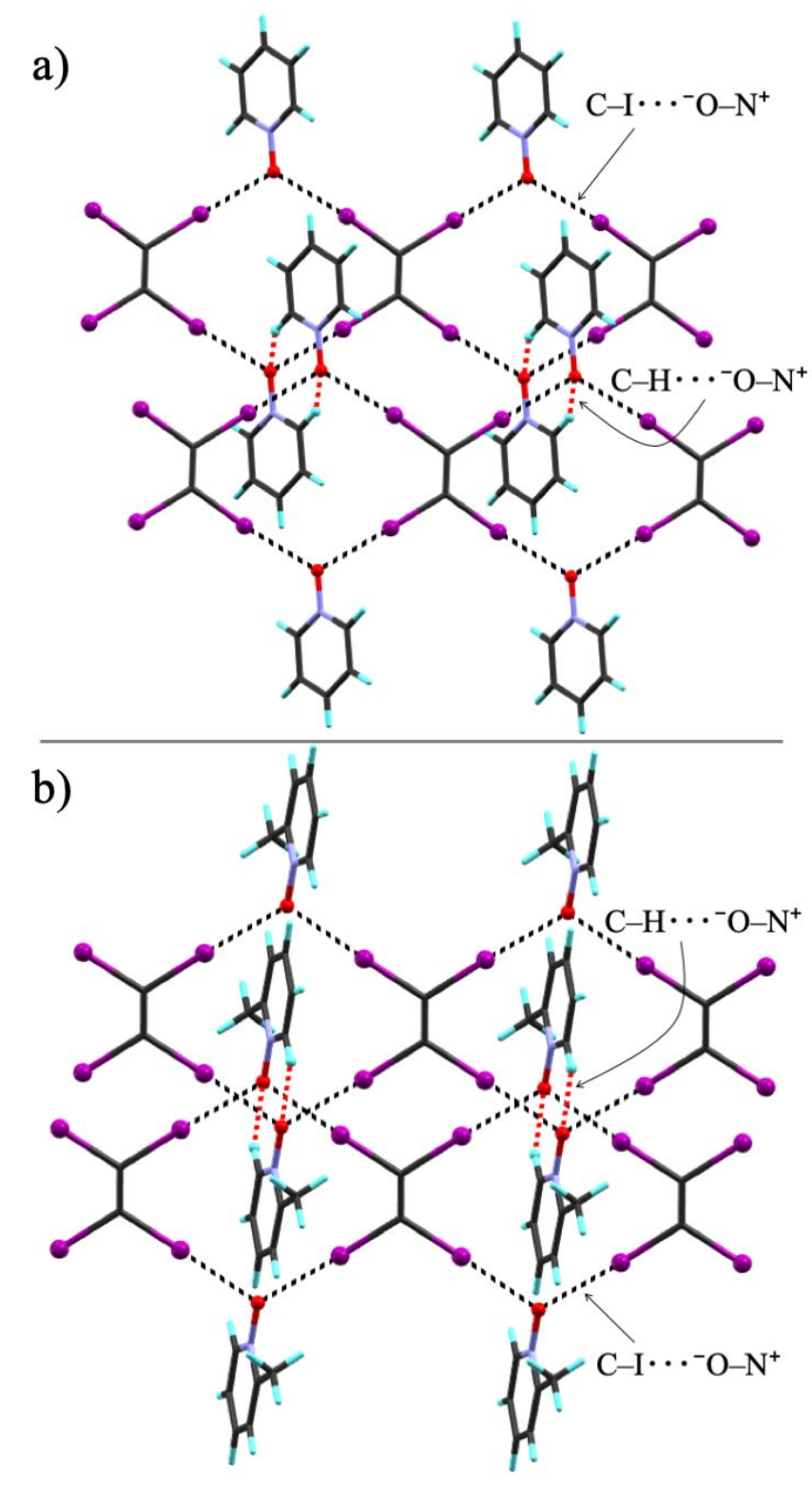

Figure 3. X-ray crystal structure packings of (a) $\mathbf{1} \cdot \mathrm{C}_{2} \mathrm{I}_{4}$, (b) $\mathbf{2} \cdot \mathrm{C}_{2} \mathrm{I}_{4}$. The black-dotted lines are $\mathrm{C}-\mathrm{I} \cdots{ }^{-} \mathrm{O}-\mathrm{N}^{+} \mathrm{XBs}$, and red-dotted lines represent $\mathrm{C}-\mathrm{H} \cdot \cdots^{-} \mathrm{O}-\mathrm{N}^{+}$interactions.

Table 1. Solid-state structure XB-bonding parameters for $\mathbf{1} \cdot \mathrm{C}_{2} \mathrm{I}_{4}-\mathbf{1 0} \cdot \mathrm{C}_{2} \mathrm{I}_{4}$.

\begin{tabular}{|c|c|c|c|c|}
\hline Complex & $d(\mathbf{I} \cdots \mathbf{O})[\AA]$ & $\angle(\mathrm{C}-\mathrm{I} \cdots \mathrm{O})\left[^{\circ}\right]$ & $d(\mathrm{C} \cdots \mathrm{O})[\AA]$ & $\mathbf{R}_{\mathbf{X B}}{ }^{1}$ \\
\hline \multirow{2}{*}{$\mathbf{1} \cdot \mathrm{C}_{2} \mathrm{I}_{4}$} & $2.777(2)$ & $178.43(13)$ & $4.892(4)$ & 0.79 \\
\hline & $2.798(3)$ & $175.16(11)$ & $4.910(5)$ & 0.80 \\
\hline \multirow{2}{*}{$\mathbf{2} \cdot \mathrm{C}_{2} \mathrm{I}_{4}$} & $2.742(6)$ & $177.5(2)$ & $4.851(10)$ & 0.78 \\
\hline & $2.812(6)$ & $177.3(2)$ & $4.916(10)$ & 0.80 \\
\hline \multirow{2}{*}{$\mathbf{3} \cdot \mathrm{C}_{2} \mathrm{I}_{4}$} & $2.771(2)$ & $176.02(16)$ & $4.883(5)$ & 0.79 \\
\hline & $2.798(3)$ & $173.10(14)$ & $4.905(6)$ & 0.80 \\
\hline \multirow{2}{*}{$4 \cdot \mathrm{C}_{2} \mathrm{I}_{4}$} & $2.794(3)$ & $177.31(12)$ & $4.911(5)$ & 0.80 \\
\hline & $2.802(3)$ & $176.49(12)$ & $4.914(5)$ & 0.80 \\
\hline $5 \cdot \mathrm{C}_{2} \mathrm{I}_{4}$ & $2.790(4)$ & $169.0(4)$ & $4.884(14)$ & 0.80 \\
\hline
\end{tabular}




\begin{tabular}{ccccc}
\hline & $2.928(4)$ & $162.0(4)$ & $4.964(14)$ & 0.84 \\
& $2.764(6)$ & $177.2(3)$ & $4.868(12)$ & 0.79 \\
$\mathbf{6} \cdot \mathrm{C}_{2} \mathrm{I}_{4}$ & $2.752(6)$ & $178.2(3)$ & $4.865(12)$ & 0.79 \\
& $2.741(6)$ & $176.0(3)$ & $4.860(12)$ & 0.78 \\
& $2.848(6)$ & $168.0(3)$ & $4.941(12)$ & 0.81 \\
$\mathbf{7} \cdot \mathrm{C}_{2} \mathrm{I}_{4}$ & $2.795(4)$ & $169.4(3)$ & $4.899(11)$ & 0.78 \\
& $2.887(4)$ & $170.6(3)$ & $4.998(11)$ & 0.83 \\
$\mathbf{8} \cdot \mathrm{C}_{2} \mathrm{I}_{4}$ & $2.832(3)$ & $165.8(3)$ & $4.934(9)$ & 0.81 \\
& $2.837(3)$ & $164.4(3)$ & $4.928(10)$ & 0.81 \\
& $2.836(6)$ & $171.9(4)$ & $4.940(15)$ & 0.81 \\
$\mathbf{9} \cdot \mathrm{C}_{2} \mathrm{I}_{4}$ & $2.942(6)$ & $165.0(4)$ & $5.000(15)$ & 0.84 \\
& $2.755(7)$ & $167.1(4)$ & $4.870(16)$ & 0.79 \\
& $3.045(7)$ & $172.4(4)$ & $5.172(16)$ & 0.87 \\
& $2.800(9)$ & $165.5(5)$ & $4.882(19)$ & 0.80 \\
& $2.850(9)$ & $166.3(5)$ & $4.943(19)$ & 0.81 \\
& $2.840(9)$ & $168.2(5)$ & $4.949(19)$ & 0.81 \\
$\mathbf{1 0} \cdot \mathrm{C}_{2} \mathrm{I}_{4}$ & $2.807(9)$ & $166.3(5)$ & $4.890(19)$ & 0.80 \\
& $2.787(9)$ & $166.1(5)$ & $4.875(17)$ & 0.80 \\
& $2.789(9)$ & $166.2(5)$ & $4.883(17)$ & 0.80 \\
& $2.859(9)$ & $168.2(5)$ & $4.972(17)$ & 0.82 \\
& $2.875(9)$ & $167.0(5)$ & $4.966(17)$ & 0.82 \\
\hline
\end{tabular}

${ }^{1}$ The $\mathrm{R}_{\mathrm{XB}}$, is defined as $\left[\mathrm{R}_{\mathrm{XB}}=d_{\mathrm{XB}} /\left(\mathrm{X}_{\mathrm{vdw}}+\mathrm{B}_{\mathrm{vdw}}\right)\right]$, where $d_{\mathrm{XB}}[\AA]$ is the distance between donor $(\mathrm{X})$ and the acceptor atoms $(\mathrm{B}), \mathrm{X}_{\mathrm{vdw}}$ and $\mathrm{B}_{\mathrm{vdw}}$ are van der Waals (vdW) radii $[\AA]$ of the corresponding atoms; the vdW radii determined by Bondi were used to calculate the $\mathrm{R}_{\mathrm{XB}}$ values. ${ }^{46}$ 


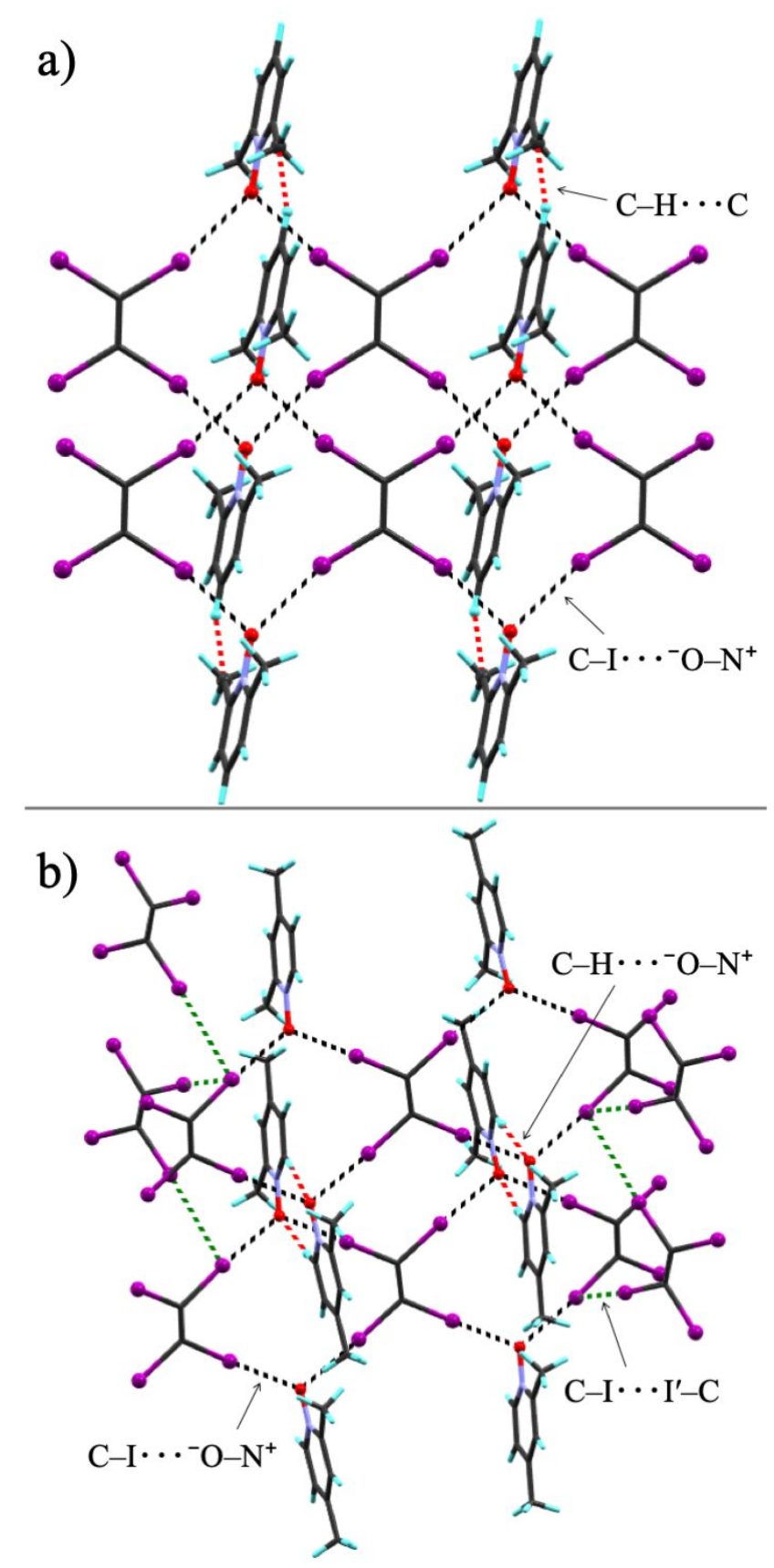

Figure 4. X-ray crystal structure packings of (a) $5 \cdot \mathrm{C}_{2} \mathrm{I}_{4}$, and (b) $6 \cdot \mathrm{C}_{2} \mathrm{I}_{4}$. The black-dotted lines represent $\mathrm{C}-\mathrm{I} \cdot \cdots^{-} \mathrm{O}-\mathrm{N}^{+} \mathrm{XBs}$, and red-dotted lines are $\mathrm{C}-\mathrm{H} \cdots{ }^{-} \mathrm{O}-\mathrm{N}^{+} / \mathrm{C}-\mathrm{H} \cdot \cdots \mathrm{C}$ interactions.

As depicted in Figure 5, the $N$-oxide oxygen of phenyl-substituted ligands in $9 \cdot \mathrm{C}_{2} \mathrm{I}_{4}$ and $\mathbf{1 0} \cdot \mathrm{C}_{2} \mathrm{I}_{4}$, is $\mu_{3^{-}}$(one $\mathrm{HB}$ and two XBs), while in $\mathbf{8} \cdot \mathrm{C}_{2} \mathrm{I}_{4}$, it is $\mu_{2^{-}}$(two XBs) coordinating. Complex $8 \cdot \mathrm{C}_{2} \mathrm{I}_{4}$ forms a 2-D sheet structure via bidentate $\mathrm{C}-\mathrm{I} \cdots{ }^{-} \mathrm{O}-\mathrm{N}^{+}$XBs and $\mathrm{C}-\mathrm{H} \cdots \mathrm{C}$ (ca. 2.74 and $2.75 \AA$ ) contacts [see Figure 5(a)]. The ortho-quinoid structure in 
2-phenylpyridine $\mathrm{N}$-oxides potentially renders the para-C-H protons on the phenyl-substituents electronically active to result in a bifurcated $\mathrm{C}-\mathrm{H} \cdots \mathrm{C}$ HBs between $\mathrm{C}-$ $\mathrm{H}$ and $\pi$-system of $\mathrm{C}_{2} \mathrm{I}_{4}$. The asymmetric unit of $9 \cdot \mathrm{C}_{2} \mathrm{I}_{4}$ contains two full $N$-oxide ligands, a full $\mathrm{C}_{2} \mathrm{I}_{4}$, and two independent $\mathrm{C}_{2} \mathrm{I}_{4}$ molecules that are on two separate centers of symmetry. Each $\mathrm{N}$-oxide and a centrosymmetric $\mathrm{C}_{2} \mathrm{I}_{4}$ donor bind through bidentate $\mathrm{C}-\mathrm{I} \cdot{ }^{-}{ }^{-} \mathrm{O}-\mathrm{N}^{+} \mathrm{XBs}$ form two parallel 1-D polymeric chains. In the packing, these 1-D chains interdigitate by $\pi-\pi$ interactions generating a "porous-like" network [see Figure S3] that has enough space for the third, $\mathrm{C}_{2} \mathrm{I}_{4}$ molecule to establish $\mathrm{C}-\mathrm{I} \cdots \mathrm{I}^{\prime}-\mathrm{C}$ XB contacts [note: $\mathrm{I}^{\prime}=\mathrm{XB}$-acceptor, $3.659 \AA\left[\angle\left(\mathrm{C}-\mathrm{I} \cdots \mathrm{I}^{\prime}\right)=170.4^{\circ}\right]$, and $\left.3.833 \AA\left[\angle\left(\mathrm{C}-\mathrm{I} \cdots \mathrm{I}^{\prime}\right)=166.7^{\circ}\right)\right]$ as depicted in Figure 5(b) with green-dotted lines from the orange-highlighted molecule. The $\mathrm{C}-\mathrm{H} \cdots{ }^{-} \mathrm{O}-\mathrm{N}^{+}$ contacts $[2.285 \AA]$ also help to stabilize the 1-D chains in addition to several weak $\mathrm{C}-\mathrm{H} \cdots \mathrm{I}$ interactions between acceptor phenyl ring and donor halogen. Asymmetric unit of complex $\mathbf{1 0} \cdot \mathrm{C}_{2} \mathrm{I}_{4}$, crystallized in the monoclinic space group $C 2$, contains four $N$-oxide ligands, a $\mathrm{C}_{2} \mathrm{I}_{4}$ and two $\mathrm{C}_{2} \mathrm{I}_{4}$ molecules on 2-fold symmetry. The four iodine atoms of a $\mathrm{C}_{2} \mathrm{I}_{4}$ molecule are engaged in $\mathrm{C}-\mathrm{I} \cdot \cdots^{-} \mathrm{O}-\mathrm{N}^{+} \mathrm{XBs}$ generating tight packing structure that is supported by the $\pi-\pi$ interactions between rod-like acceptor ligands [see Figure S4]. 
a)

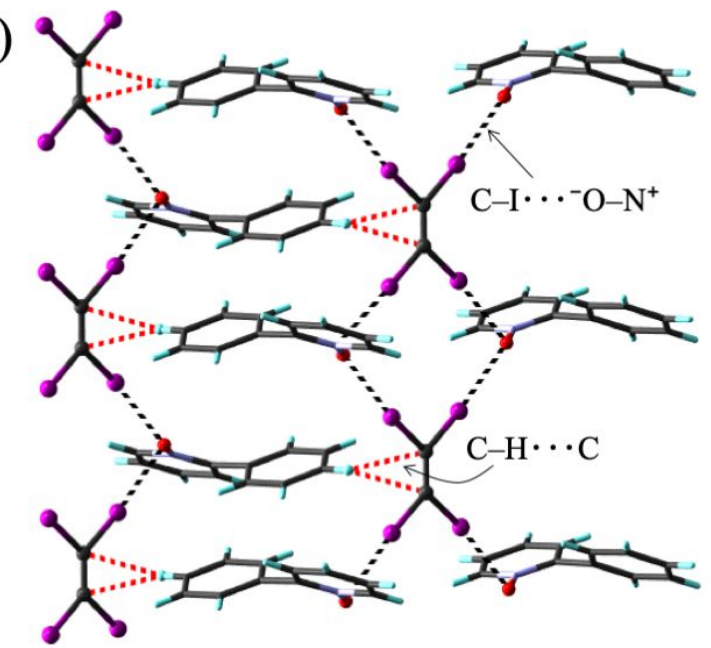

b)

$\longrightarrow$

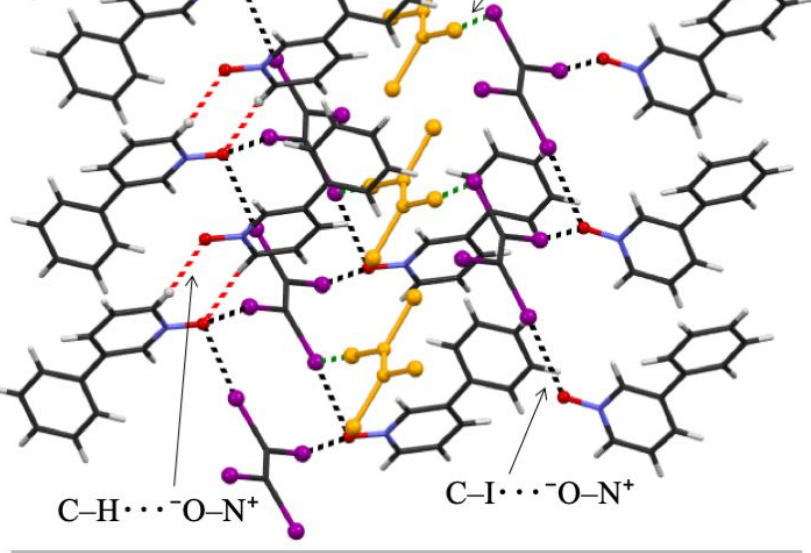

c)

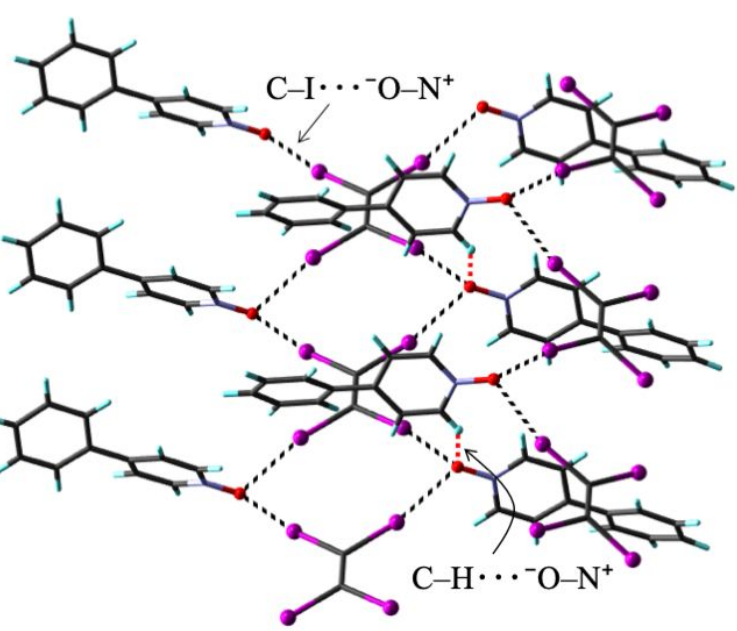

Figure 5. X-ray crystal structure packings of (a) $\mathbf{8} \cdot \mathrm{C}_{2} \mathrm{I}_{4}$, (b) $\mathbf{9} \cdot \mathrm{C}_{2} \mathrm{I}_{4}$, and (c) $\mathbf{1 0} \cdot$ $\mathrm{C}_{2} \mathrm{I}_{4}$. The black-dotted lines are $\mathrm{C}-\mathrm{I} \cdot \cdots^{-} \mathrm{O}-\mathrm{N}^{+} \mathrm{XBs}$, red represent $\mathrm{C}-\mathrm{H} \cdot \cdots^{-} \mathrm{O}-\mathrm{N}^{+}$ $\mathrm{HBs}$, and the green are $\mathrm{C}-\mathrm{I} \cdots \mathrm{I}^{\prime}-\mathrm{C}$ interactions. 
The accurate study by Lommerse et $a l .{ }^{61}$ on $\mathrm{C}-\mathrm{X} \cdots \mathrm{O}(\mathrm{X}=\mathrm{F}, \mathrm{Cl}, \mathrm{Br}, \mathrm{I})$ type interactions demonstrated that the more electron-withdrawing the $s p^{3}$-carbon of halocarbon is, the stronger the $\mathrm{X}$-bond formation is. This fact explains the narrow range of $\mathrm{C} \cdots \mathrm{O}$ distances in 1, $\square$-diiodoperfluoroalkanes and PyNOs [see Figure S5(b), Type b] compared to iodoperfluoroarenes and PyNOs [see Figure S5(c), Type c], which is in agreement with the narrow range $\mathrm{N} \cdots \mathrm{O}$ distances when strong $\mathrm{XBs}$ are formed between $\mathrm{N}$-iodosaccharin and PyNOs [see Figure S5(a), Type a]. By comparison, the C $\cdots \mathrm{O}$ distances of the non-fluorinated $\mathrm{C}_{2} \mathrm{I}_{4}$ donor vary in a narrow range for $\mathbf{1} \cdot \mathrm{C}_{2} \mathrm{I}_{4}-\mathbf{1 0} \cdot \mathrm{C}_{2} \mathrm{I}_{4}[4.851(10)-$ 5.172(16) A, Figure S5(d)], making them more akin to Type b than Type c XBs. This comparison demonstrates the more efficient overlap of O-atom lone-pair and the $p$-orbital of halogen in Type b relative to Type c. In addition to the electron-withdrawing parameter, the $\pi$-bond also plays an important role to enhance the $\sigma$-hole strength. This is verified by calculating $\sigma$-hole strength $\mathrm{V}_{s, \max }$ values of saturated haloalkanes, namely, $1,1^{\prime}, 2,2^{\prime}$-tetraiodoethane $\left(102 \mathrm{~kJ} \mathrm{~mol}^{-1}\right)$ and hexaiodoethane $\left(113 \mathrm{~kJ} \mathrm{~mol}^{-1}\right)$ in comparison to $\mathrm{C}_{2} \mathrm{I}_{4}$. Both saturated haloalkanes have $\mathrm{V}_{S \text {, max }}$ values smaller than $\mathrm{C}_{2} \mathrm{I}_{4}\left(117 \mathrm{~kJ} \mathrm{~mol}^{-1}\right.$, see Figure 6). Furthermore, the $\mathrm{V}_{\mathrm{s}, \max }$ of $\mathrm{C}_{2} \mathrm{I}_{4}$ iodines is notably larger than those of iodobenzene $\quad\left(67 \mathrm{~kJ} \mathrm{~mol}^{-1}\right),{ }^{47} \quad 1,4$-di-iodobenzene $\quad\left(108 \mathrm{~kJ} \mathrm{~mol}^{-1}\right),{ }^{48}$ 3,5-difluoro-1-iodobenzene $\quad\left(98 \mathrm{~kJ} \mathrm{~mol}^{-1}\right),{ }^{47} \quad$ 3,5-bis(trifluoromethyl)-1-iodobenzene $\left(115 \mathrm{~kJ} \mathrm{~mol}^{-1}\right),{ }^{47}$ para-phenyl bound iodine of 1-iodoethynyl-4-iodobenzene $\left(107 \mathrm{~kJ} \mathrm{~mol}^{-}\right.$ $\left.{ }^{1}\right)^{48}$ or 1-bromoethynyl-4-iodobenzene $\left(105 \mathrm{~kJ} \mathrm{~mol}^{-1}\right),{ }^{48}$ which can be accounted by the shorter olefinic system. 


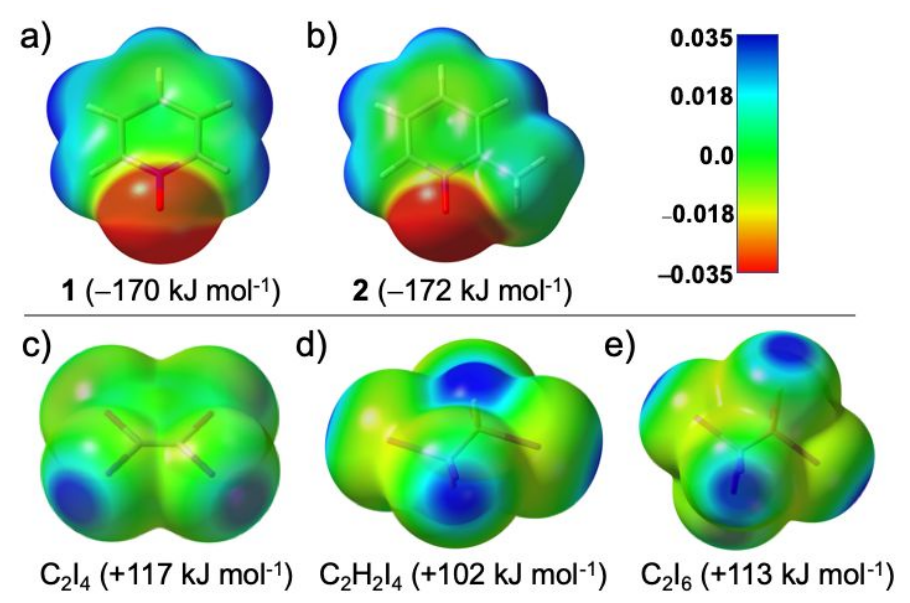

Figure 6. Computed electrostatic potentials projected on the 0.001 a.u. electron density surfaces of selected PyNO acceptors with $\mathrm{V}_{\mathrm{S} \text {,min }}$ values, (a) 1, (b) 2, and donors (c) $\mathrm{C}_{2} \mathrm{I}_{4}$, (d) $\mathrm{C}_{2} \mathrm{H}_{2} \mathrm{I}_{4}$ (e) $\mathrm{C}_{2} \mathrm{I}_{6}$ with $\mathrm{V}_{\mathrm{S} \text {,max }}$ values.

Monodentate bonding motifs of $\mathrm{C}_{2} \mathrm{I}_{4}$ halogen bond complexes were optimized with 13 PyNO acceptors. The $\mathrm{C}-\mathrm{I} \cdot \cdots^{-} \mathrm{O}-\mathrm{N}^{+} \mathrm{XBs}$ in optimized structures span a narrower range $2.756-2.887 \AA$ [see Table 2] than the XBs found in crystal structures [2.741(6) - 3.045(7) $\AA]$. The XB distances of optimized structures are on average also shorter than in the experimental structures which is to be expected given the bidentate $\mu_{2}$-XB-coordination of the $N$-oxide oxygens in the solid-state. In the cases of $\mathbf{2} \cdot \mathrm{C}_{2} \mathrm{I}_{4}, \mathbf{3} \cdot \mathrm{C}_{2} \mathrm{I}_{4}, \mathbf{4} \cdot \mathrm{C}_{2} \mathrm{I}_{4}, \mathbf{6} \cdot \mathrm{C}_{2} \mathrm{I}_{4}$, and 10 $\cdot \mathrm{C}_{2} \mathrm{I}_{4}$, the optimized halogen bonds are longer than those found in the solid-state structures. This can be related to the previously observed trend that DFT calculations predict $\mathrm{N}$-oxide $\mathrm{XBs}$ longer than the corresponding experimental $\mathrm{XBs},{ }^{49}$ but also to the bonding arrangement in the optimized structures. In the absence of other interactions from surrounding molecules, that are present in the solid-state, the PyNO acceptor molecules bend in the optimized structures toward the non-halogen bonded end of $\mathrm{C}_{2} \mathrm{I}_{4}$ molecule to gain increased stabilization via dispersive interactions [see Figure S6]. This bending is evidenced by some of the optimized complexes showing $\angle(\mathrm{C}-\mathrm{I} \cdot \cdots \mathrm{O})$ angles below $170^{\circ}$ 
[see Table 2] and is likely to lengthen the XB, but increase the overall interaction between XB donor and acceptor.

Table 2. XB distances, angles, and interaction energies $\left(\Delta E_{\text {int }}\right)$ of $\mathrm{XB}$ complexes optimized at PBE0-D3/def2-TZVP level of theory.

\begin{tabular}{cccc}
\hline Complex & $\mathbf{I} \cdots \mathbf{O}[\AA]$ & $\begin{array}{c}\boldsymbol{L}(\mathbf{C}-\mathbf{I} \boldsymbol{\cdots} \mathbf{O}) \\
{\left[{ }^{\circ}\right]}\end{array}$ & $\begin{array}{c}\Delta \boldsymbol{E}_{\text {int }}[\mathbf{k J} \\
\left.\mathbf{m o l}^{-\mathbf{1}}\right]\end{array}$ \\
\hline $\mathbf{1} \cdot \mathrm{C}_{2} \mathrm{I}_{4}$ & 2.756 & 172.3 & 31.9 \\
$\mathbf{2} \cdot \mathrm{C}_{2} \mathrm{I}_{4}$ & 2.836 & 161.5 & 37.2 \\
$\mathbf{3} \cdot \mathrm{C}_{2} \mathrm{I}_{4}$ & 2.837 & 161.2 & 37.7 \\
$\mathbf{4} \cdot \mathrm{C}_{2} \mathrm{I}_{4}$ & 2.813 & 162.0 & 37.2 \\
$\mathbf{5} \cdot \mathrm{C}_{2} \mathrm{I}_{4}$ & 2.741 & 173.3 & 38.5 \\
$\mathbf{6} \cdot \mathrm{C}_{2} \mathrm{I}_{4}$ & 2.812 & 161.8 & 40.0 \\
$\mathbf{7} \cdot \mathrm{C}_{2} \mathrm{I}_{4}$ & 2.837 & 160.9 & 42.2 \\
$\mathbf{8} \cdot \mathrm{C}_{2} \mathrm{I}_{4}$ & 2.733 & 171.9 & 38.5 \\
$\mathbf{9} \cdot \mathrm{C}_{2} \mathrm{I}_{4}$ & 2.858 & 164.9 & 44.3 \\
$\mathbf{1 0} \cdot \mathrm{C}_{2} \mathrm{I}_{4}$ & 2.887 & 160.2 & 39.2 \\
$\mathbf{1 1} \cdot \mathrm{C}_{2} \mathrm{I}_{4}$ & 2.752 & 175.5 & 45.7 \\
$\mathbf{1 2} \cdot \mathrm{C}_{2} \mathrm{I}_{4}$ & 2.747 & 174.8 & 43.1 \\
$\mathbf{1 3} \cdot \mathrm{C}_{2} \mathrm{I}_{4}$ & 2.744 & 175.7 & 46.5 \\
\hline
\end{tabular}

The interaction energies used to describe the strength of halogen bonding are between $31.9-46.5 \mathrm{~kJ} \mathrm{~mol}^{-1}$ for the optimized structures suggesting $\mathrm{C}_{2} \mathrm{I}_{4}$ forms XBs with PyNO that are similar in strength to reported $\mathrm{I}-\mathrm{I} \cdots{ }^{-} \mathrm{O}-\mathrm{N}^{+}=42.0 \mathrm{~kJ} \mathrm{~mol}^{-1}, 50$ and $\mathrm{CF}_{3}-\mathrm{I}^{\cdots}{ }^{-} \mathrm{O}-\mathrm{N}^{+}=$ $33.7 \mathrm{~kJ} \mathrm{~mol}{ }^{-1} .{ }^{38}$ Furthermore, despite the different $\mathrm{V}_{s, \max }$ values for $\mathrm{C}_{2} \mathrm{I}_{4}\left[117 \mathrm{~kJ} \mathrm{~mol}^{-1}\right]$, $\mathrm{CF}_{3} \mathrm{I}\left[129 \mathrm{~kJ} \mathrm{~mol}^{-1}\right]$, and $\mathrm{C}_{6} \mathrm{~F}_{5} \mathrm{I}\left[134 \mathrm{~kJ} \mathrm{~mol}^{-1}\right]$ (see Figure S8), the calculated monodentate XB interaction energy of $\mathbf{1} \cdot \mathrm{C}_{2} \mathrm{I}_{4}\left[31.9 \mathrm{~kJ} \mathrm{~mol}^{-1}\right]$ was found to be similar to complexes, $\mathbf{1}$. $\mathrm{CF}_{3} \mathrm{I}\left[31.1 \mathrm{~kJ} \mathrm{~mol}^{-1}\right]$ and $\mathbf{1} \cdot \mathrm{C}_{6} \mathrm{~F}_{5} \mathrm{I}\left[32.3 \mathrm{~kJ} \mathrm{~mol}^{-1}\right]$. This result is a little surprising but more of a reminder that the relative strengths of $\mathrm{XBs}$ are not solely determined by the $\mathrm{V}_{s, \max }$ values but also by the polarization of the $\mathrm{XB}$ donors in the presence of the $\mathrm{XB}$ acceptors as shown by Clark and Heßelmann. ${ }^{51}$ These observations agree with the CSD statistical analysis on XBs between carbon-bound halogens and O-atom carried out by Lommerse et 
al., that suggested the interaction strengths of donors to follow the trend, $\mathrm{X}-\mathrm{X}>(s p) \mathrm{C}-\mathrm{X}>$ $\left(s p^{2}\right) \mathrm{C}-\mathrm{X}>\left(s p^{3}\right) \mathrm{C}-\mathrm{X} .{ }^{52}$

The $\mathrm{XB}$ distances and $\Delta E_{\text {int }}$ do not correlate very closely in the optimized structures which indicates some of the optimized complexes are stabilized by other interactions in addition to the halogen bonding. To investigate the relative strengths of XBs and other interactions between $\mathrm{C}_{2} \mathrm{I}_{4}$ and pyridine-N-oxide a dimer structure of $\mathbf{1} \cdot \mathrm{C}_{2} \mathrm{I}_{4}$ was optimized and analyzed with the quantum theory of atoms in molecules (QTAIM) method ${ }^{53}$ [see Figure S7]. QTAIM analysis showed hydrogen bond interactions between PyNO ligands and interactions from halogen bonded and non-halogen bonded iodine to $\pi$-cloud of the pyridine ring in addition to the XBs. Halogen bonds were clearly the strongest intermolecular interaction in the analysis while the others remained in a supporting role.

Adding electron-donating groups to PyNO increase the $\mathrm{V}_{\mathrm{s}, \mathrm{min}}$ of oxygen as illustrated in Figure 6 and increase the strength of XBs as shown by the calculated $\Delta E_{\text {int }}$ [see Table 2]. Halogen bonds of the phenyl substituted PyNOs are stronger than the methyl-substituted and diphenyl- and triphenyl-substituted PyNOs are calculated to form the strongest halogen bonds with $\mathrm{C}_{2} \mathrm{I}_{4}$. This contrasts with the experimental failure of obtaining crystals of complexes, $\mathbf{1 1} \cdot \mathrm{C}_{2} \mathrm{I}_{4}-\mathbf{1 3} \cdot \mathrm{C}_{2} \mathrm{I}_{4}$. The discrepancy can be related to the size difference of the XB-donor and acceptor molecules that is likely to hinder the efficient packing of the complexes into a crystal structure.

It has been previously observed in systems of small XB-donors displaying multiple XB-interactions that the presence of a second or third halogen bond can enhance the overall strengths of halogen bonds. ${ }^{54-56}$ Here in the reported solid-state structures, the $\mathrm{C}_{2} \mathrm{I}_{4}$ molecules act as square planar tetrakis XB donors. To qualitatively estimate if having $\mathrm{C}_{2} \mathrm{I}_{4}$ act as donor to more than one XB influences the strengths of individual halogen bonds, we optimized XB motifs of $\mathrm{C}_{2} \mathrm{I}_{4}$ with multiple 1 as acceptors [see Figure S9]. Comparison of 
the interaction energies showed that having more than one $\mathrm{XB}$ acceptor to interact with the $\mathrm{C}_{2} \mathrm{I}_{4}$ does not significantly change the strength of each $\mathrm{XB}$ and $\mathrm{C}_{2} \mathrm{I}_{4}$ can effectively act as tetrakis XB donor [see Table S3]. In X-ray structures of $\mathbf{5} \cdot \mathrm{C}_{2} \mathrm{I}_{4}$ and $\mathbf{7} \cdot \mathrm{C}_{2} \mathrm{I}_{4}-\mathbf{1 0} \cdot \mathrm{C}_{2} \mathrm{I}_{4}$, donor molecules were disordered and showed both vic- and gem-bonding modes towards $N$-oxide acceptors. To estimate the energy difference between the vic- and gem-bonding modes, we have optimized dimer model structures for $\mathrm{C}_{2} \mathrm{I}_{4}$ and $\mathbf{1}$ shown in Figure 7 (b and $\mathbf{c}$ structures, respectively). The vic-bonded dimer was calculated as the more strongly bound structure between $\mathrm{C}_{2} \mathrm{I}_{4}$ and 1 with $\Delta E_{\text {int }}$ of $28.9 \mathrm{~kJ} \mathrm{~mol}^{-1}$ per halogen bond in agreement with the experimental crystal structure of $\mathbf{1} \cdot \mathrm{C}_{2} \mathrm{I}_{4}$ that shows only vic-bonding mode. However, the energy difference between the vic- and gem-bonding modes is relatively small with the $\Delta E_{\text {int }}$ of gem-bonded dimer being only $2.4 \mathrm{~kJ} \mathrm{~mol}^{-1}$ smaller per $\mathrm{XB}$ bond than the vic-bonded dimer. The small energy difference between the two bonding modes agrees with the observation of disorder in $\mathbf{5} \cdot \mathrm{C}_{2} \mathrm{I}_{4}$ and $\mathbf{7} \cdot \mathrm{C}_{2} \mathrm{I}_{4}-\mathbf{1 0} \cdot \mathrm{C}_{2} \mathrm{I}_{4}$ crystal structures.

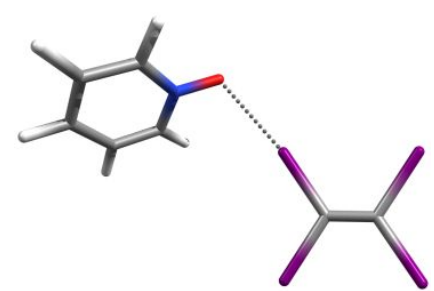

a

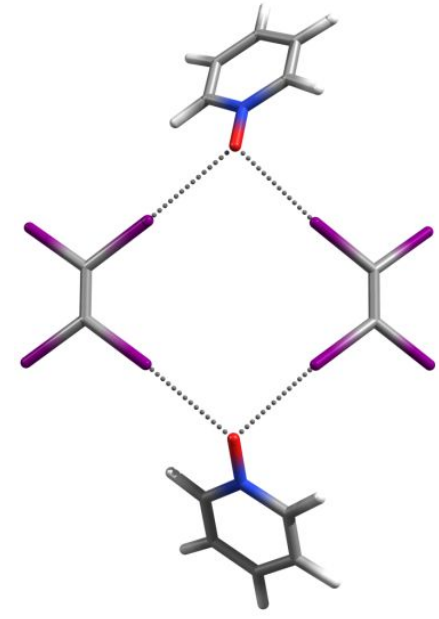

b

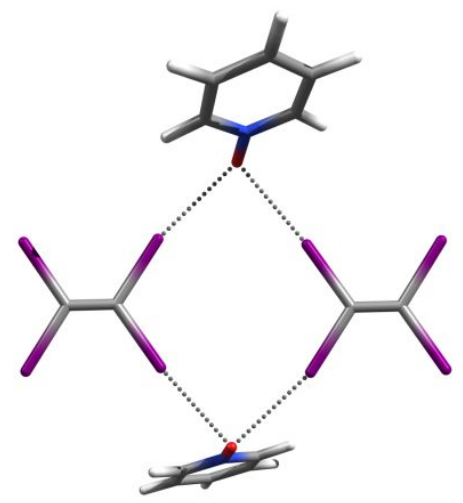

C

Figure 7. XB motifs featuring 1 and $\mathrm{C}_{2} \mathrm{I}_{4}$ optimized at PBE0-D3/def2-TZVP level of theory (a 1:1 XB complex, b vic-bonded dimer, and $\mathbf{c}$ gem-bonded dimer). 
To compare the relative strengths of $\mathrm{C}-\mathrm{I} \cdots \mathrm{I}^{\prime}-\mathrm{C}$ interactions between $\mathrm{C}_{2} \mathrm{I}_{4}$ molecules found in $\mathbf{6} \cdot \mathrm{C}_{2} \mathrm{I}_{4}$ and $\mathbf{9} \cdot \mathrm{C}_{2} \mathrm{I}_{4}$ with the XB interactions between $\mathrm{C}_{2} \mathrm{I}_{4}$ donors and $N$-oxide acceptors, several attempts were made to optimize structures with two $\mathrm{C}_{2} \mathrm{I}_{4}$ that would have corresponded to the experimentally observed XB bonding. Optimized structures tended to exhibit other interactions between $\mathrm{C}_{2} \mathrm{I}_{4}$ molecules in addition to or instead of $\mathrm{C}-\mathrm{I} \cdots \mathrm{I}^{\prime}-\mathrm{C}$ interactions. The best optimized structure exhibiting $\mathrm{C}-\mathrm{I} \cdots \mathrm{I}^{\prime}-\mathrm{C}$ interactions had one of the $\mathrm{C}_{2} \mathrm{I}_{4}$ molecules acting as a double XB donor towards two iodine atoms on the other $\mathrm{C}_{2} \mathrm{I}_{4}$ [depicted in Figure $\mathrm{S} 10$ ] with $\Delta E_{\text {int }}$ of $15.2 \mathrm{~kJ}$ mol-1 per XB. $\Delta E_{\text {int }}$ estimated in the crystal structure geometry for the shortest $\mathrm{C}-\mathrm{I} \cdots \mathrm{I}^{\prime}-\mathrm{C}$ contact $(3.659 \AA)$ found in $9 \cdot \mathrm{C}_{2} \mathrm{I}_{4}$ was $14.5 \mathrm{~kJ} \mathrm{~mol}^{-1}$. These results suggest that the $\mathrm{C}-\mathrm{I} \cdots \mathrm{I}^{\prime}-\mathrm{C}$ interactions are roughly one half in strength compared to the interactions between $\mathrm{C}_{2} \mathrm{I}_{4}$ and $N$-oxide acceptors.

\section{CONCLUSIONS}

In summary, the $\mathrm{C}-\mathrm{I} \cdot \cdots^{-} \mathrm{O}-\mathrm{N}^{+}$halogen bonds involving tetraiodoethylene donor were systematically studied against 13 aromatic $N$-oxide acceptors. The solid-state halogen bond parameters demonstrate that the $\mathrm{C}-\mathrm{I} \cdots{ }^{-} \mathrm{O}-\mathrm{N}^{+}$interactions are directional and the distances are close to those formed between perfluorohaloalkanes/-arenes and $\mathrm{N}$-oxides, suggesting the iodine of non-fluorinated $\mathrm{C}_{2} \mathrm{I}_{4}$ is a strong halogen bond donor comparable to fluorinated donors in crystals. It is possible to enhance the halogen atom $\sigma$-hole strength not only by using electron-withdrawing fluorine atoms but also by designing $\pi$-bonded small-molecule systems. The $\mathrm{C}_{2} \mathrm{I}_{4}-\mathrm{V}_{\mathrm{s} \text {,max }}$ value of $117 \mathrm{~kJ} \mathrm{~mol}^{-1}$ obtained by DFT calculations is comparable with known fluorinated donors, for example 3,5-difluoroiodobenzene $\left(109 \mathrm{~kJ} \mathrm{~mol}^{-1}\right)$ and 2,6-difluoroiodobenzene $\left(107 \mathrm{~kJ} \mathrm{~mol}^{-1}\right)$. Our results show that tetraiodoethylene has not gained the attention it deserves in halogen bonding, and there remains a great deal to be explored in using tetraiodoethylene as a non-fluorinated halogen bond donor for 
supramolecular design. Our results further demonstrate that different from perfluorinated $\mathrm{XB}$-donors that are prone to weakened $\mathrm{XB}$ interaction strengths due to $\mathrm{F} \cdots \mathrm{F}$ aggregation, the tetraiodoethylene can be the ideal candidate to define inherent characteristics of XBs in crystals by minimizing competing weak interactions.

\section{EXPERIMENTAL SECTION}

All solvents employed for synthesis and crystallization experiments were commercially purchased and were used as received without any purification. Aromatic $N$-oxides, 1-4, 10, and tetraiodoethylene $\left(\mathrm{C}_{2} \mathrm{I}_{4}\right)$ were purchased from Sigma Aldrich. Aromatic $N$-oxides, 5, 6, 7, 8, 9, and 11-13 were synthesized by oxidation of their corresponding $N$-heterocyclic compounds using procedures as reported by Katritzky and Lagowski. ${ }^{57}$ Single-crystal X-ray data for halogen bonded complexes were obtained either by using a Bruker-Nonius Kappa CCD diffractometer or a Rigaku SuperNova Oxford diffractometer. Full single-crystal X-ray experimental details for complexes $\mathbf{1} \cdot \mathrm{C}_{2} \mathrm{I}_{4}-\mathbf{1 0} \cdot \mathrm{C}_{2} \mathrm{I}_{4}$ (CCDC numbers: 1992629-1992638) are given in the Supporting Information. All calculations were carried out with Gaussian 16 program package ${ }^{58}$ and employing PBE0 hybrid DFT functional, ${ }^{59-62}$ def2-TZVP basis sets that utilize effective core potentials for iodine atoms, ${ }^{63,64}$ and D3BJ dispersion correction (PBE0-D3/def2-TZVP). ${ }^{65}$ Basis set superposition errors were treated with the counterpoise method. ${ }^{66}$ The selected PBE0-D3/def2-TZVP calculation method has been previously used to successfully model the interactions in other sigma-hole acceptor complexes of substituted pyridine $N$-oxides by us $^{38,49}$ and others. ${ }^{67}$ AIMAll program was used to determine the electrostatic surface potential extremes. ${ }^{68}$ 


\begin{abstract}
ASSOCIATED CONTENT
SUPPORTING INFORMATION

The Supporting Information is available free of charge on the ACS Publication website at DOI: XXXXX. X-ray experimental details and computational data are included in the Supporting Information.
\end{abstract}

\title{
ACKNOWLEDGMENTS
}

The research work is funded by Academy of Finland (RP: grant no. 298817), and Prof. H. M. Tuononen (University of Jyvaskyla) provided the computational resources. The authors gratefully acknowledge University of Jyvaskyla for providing laboratory and SCXRD resources.

\section{REFERENCES}

(1) Desiraju, G.R.; Ho, P.S.; Kloo, L.; Legon, A.C.; Marquardt, R.; Metrangalo, P.; Politzer, O.; Resnati, G.; Rissanen, K. Definition of the Halogen Bond (IUPAC Recommendations 2013). 2013, 1711-1713. https://doi.org/10.1351/PAC-REC-12-05-10.

(2) Mukherjee, A.; Tothadi, S.; Desiraju, G. R. Halogen Bonds in Crystal Engineering: Like Hydrogen Bonds yet Different. Acc. Chem. Res. 2014, 47, 2514-2524. https://doi.org/10.1021/ar5001555.

(3) Brown, A.; Beer, P. D. Halogen Bonding Anion Recognition. Chem. Commun. 2016, 
52, 8645-8658. https://doi.org/10.1039/C6CC03638D.

(4) Bulfield, D.; Huber, S. M. Halogen Bonding in Organic Synthesis and Organocatalysis. Chem. $\quad-\quad A$ Eur. J. 2016, 22, 14434-14450. https://doi.org/10.1002/chem.201601844.

(5) Politzer, P.; Murray, J. S. Halogen Bonding: An Interim Discussion. ChemPhysChem 2013, 14, 278-294. https://doi.org/10.1002/cphc.201200799.

(6) Politzer, P.; Murray, J. S.; Clark, T. Halogen Bonding and Other [Sigma]-Hole Interactions: A Perspective. Phys. Chem. Chem. Phys. 2013, 15, 11178-11189. https://doi.org/10.1039/C3CP00054K.

(7) Eskandari, K.; Lesani, M. Does Fluorine Participate in Halogen Bonding? Chem. - A Eur. J. 2015, 21, 4739-4746. https://doi.org/10.1002/chem.201405054.

(8) Clark, T.; Hennemann, M.; Murray, J. S.; Politzer, P. Halogen Bonding: The $\sigma$-Hole. J. Mol. Model. 2007, 13, 291-296. https://doi.org/10.1007/s00894-006-0130-2.

(9) Riley, K.; Murray, J.; Fanfrlík, J.; Řezáč, J.; Solá, R.; Concha, M.; Ramos, F.; Politzer, P. Halogen Bond Tunability I: The Effects of Aromatic Fluorine Substitution on the Strengths of Halogen-Bonding Interactions Involving Chlorine, Bromine, and Iodine. J. Mol. Model. 2011, 17, 3309-3318. https://doi.org/10.1007/s00894-011-1015-6.

(10) Tsuzuki, S.; Uchimaru, T.; Wakisaka, A.; Ono, T.; Sonoda, T. CCSD(T) Level 
Interaction Energy for Halogen Bond between Pyridine and Substituted Iodobenzenes: Origin and Additivity of Substituent Effects. Phys. Chem. Chem. Phys. 2013, 15, 6088-6096. https://doi.org/10.1039/C3CP43693D.

(11) Fourmigué, M. Halogen Bonding: Recent Advances. Curr. Opin. Solid State Mater. Sci. 2009, 13, 36-45. https://doi.org/http://dx.doi.org/10.1016/j.cossms.2009.05.001.

(12) Cavallo, G.; Metrangolo, P.; Milani, R.; Pilati, T.; Priimagi, A.; Resnati, G.; Terraneo, G. The Halogen Bond. Chem. Rev. 2016, 116, 2478-2601. https://doi.org/10.1021/acs.chemrev.5b00484.

(13) Metrangolo, P.; Resnati, G.; Arman, H. D. Halogen Bonding: Fundamentals and Applications; Structure and Bonding; Springer, 2008.

(14) Wilcken, R.; Zimmermann, M. O.; Lange, A.; Joerger, A. C.; Boeckler, F. M. Principles and Applications of Halogen Bonding in Medicinal Chemistry and Chemical Biology. J. Med. Chem. 2013, 56, 1363-1388. https://doi.org/10.1021/jm3012068.

(15) Larionov, O. V. Heterocyclic N-Oxides; Topics in Heterocyclic Chemistry; Springer International Publishing, 2017.

(16) Puttreddy, R.; Topić, F.; Valkonen, A.; Rissanen, K. Halogen-Bonded Co-Crystals of Aromatic N-Oxides: Polydentate Acceptors for Halogen and Hydrogen Bonds. Crystals 2017, 7, 214. https://doi.org/10.3390/cryst7070214. 
(17) The Cambridge Structural Database, Version 2.0.5 (Last Updated, March 2020).

(18) Yamamoto, H. M.; Yamaura, J.-I.; Kato, R. Multicomponent Molecular Conductors with Supramolecular Assembly: Iodine-Containing Neutral Molecules as Building Blocks. J. Am. Chem. Soc. 1998, 120, 5905-5913. https://doi.org/10.1021/ja980024u.

(19) Yamamoto, H. M.; Kosaka, Y.; Maeda, R.; Yamaura, J.; Nakao, A.; Nakamura, T.; Kato, R. Supramolecular Insulating Networks Sheathing Conducting Nanowires Based on Organic Radical Cations. ACS Nano 2008, 2, 143-155. https://doi.org/10.1021/nn700035t.

(20) Walsh, R. D.; Smith, J. M.; Hanks, T. W.; Pennington, W. T. Computational and Crystallographic Studies of Pseudo-Polyhalides. Cryst. Growth Des. 2012, 12, 2759 2768. https://doi.org/10.1021/cg201231t.

(21) Wang, H.; Zhao, X. R.; Jin, W. J. The C-I $\cdots \mathrm{X}^{-}$Halogen Bonding of Tetraiodoethylene with Halide Anions in Solution and Cocrystals Investigated by Experiment and Calculation. Phys. Chem. Chem. Phys. 2013, 15, 4320-4328. https://doi.org/10.1039/C3CP43865A.

(22) Kobra, K.; O’Donnell, S.; Ferrari, A.; McMillen, C. D.; Pennington, W. T. Halogen Bonding and Triiodide Asymmetry in Cocrystals of Triphenylmethylphosphonium Triiodide with Organoiodines. New J. Chem. 2018, 42, 10518-10528. https://doi.org/10.1039/C8NJ01373J. 
(23) Dahl, T. N6,N6-Dimethyladenine-Tetraiodoethene (2/1). Acta Crystallogr. Sect. C 1999, 55, 1568-1570. https://doi.org/10.1107/S0108270199006472.

(24) Padgett, C. W.; Walsh, R. D.; Drake, G. W.; Hanks, T. W.; Pennington, W. T. New Conformations and Binding Modes in Halogen-Bonded and Ionic Complexes of 2,3,5,6-Tetra(2‘-Pyridyl)Pyrazine. Cryst. Growth Des. 2005, 5, 745-753. https://doi.org/10.1021/cg049730z.

(25) Crihfield, A.; Hartwell, J.; Phelps, D.; Walsh, R. B.; Harris, J. L.; Payne, J. F.; Pennington, W. T.; Hanks, T. W. Crystal Engineering through Halogen Bonding. 2. Complexes of Diacetylene-Linked Heterocycles with Organic Iodides. Cryst. Growth Des. 2003, 3, 313-320. https://doi.org/10.1021/cg0340042.

(26) Bailey, R. D.; Hook, L. L.; Watson, R. P.; Hanks, T. W.; Pennington, W. T. Tetraiodoethylene: A Supramolecular Host for Lewis Base Donors. Cryst. Eng. 2000, 3, 155-171. https://doi.org/https://doi.org/10.1016/S1463-0184(00)00039-3.

(27) Perkins, C.; Libri, S.; Adams, H.; Brammer, L. Diiodoacetylene: Compact, Strong Ditopic Halogen Bond Donor. CrystEngComm 2012, 14, 3033-3038. https://doi.org/10.1039/C2CE00029F.

(28) Walsh, R. B.; Padgett, C. W.; Metrangolo, P.; Resnati, G.; Hanks, T. W.; Pennington, W. T. Crystal Engineering through Halogen Bonding: Complexes of Nitrogen Heterocycles with Organic Iodides. Cryst. Growth Des. 2001, 1, 165-175. https://doi.org/10.1021/cg005540m. 
(29) Dahl, T.; Hassel, O.; Sandberg, F.; Norin, T. Crystal Structures of Tetrabromoethylene and of 1:1 Pyrazine Adducts of Tetrabromo- Resp. Tetraiodoethylene. Acta Chem. Scand. 1968, 22, 2851-2866. https://doi.org/10.3891/acta.chem.scand.22-2851.

(30) Jay, J. I.; Padgett, C. W.; Walsh, R. D. B.; Hanks, T. W.; Pennington, W. T. Noncovalent Interactions in 2-Mercapto-1-Methylimidazole Complexes with Organic Iodides. Cryst. Growth Des. 2001, 1, 501-507. https://doi.org/10.1021/cg015538a.

(31) Arman, H. D.; Gieseking, R. L.; Hanks, T. W.; Pennington, W. T. Complementary

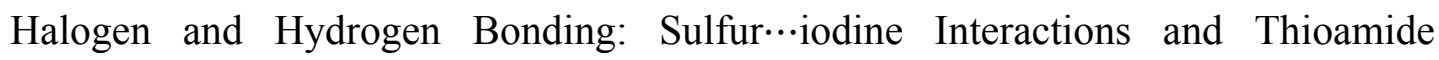
Ribbons. Chem. Commun. 2010, 46, 1854-1856. https://doi.org/10.1039/B925710A.

(32) Dahl, T.; Hassel, O. Bonds Connecting Group VI Donor Atoms and Halogen Atoms in Ethylene Derivatives. Acta Chem. Scand. 1965, 19, 2000-2001. https://doi.org/10.3891/acta.chem.scand.19-2000.

(33) Arman, H. D.; Rafferty, E. R.; Bayse, C. A.; Pennington, W. T. Complementary Selenium $\cdots$ Iodine Halogen Bonding and Phenyl Embraces: Cocrystals of Triphenylphosphine Selenide with Organoiodides. Cryst. Growth Des. 2012, 12, 4315-4323. https://doi.org/10.1021/cg201348u.

(34) Bock, H.; Holl, S. Kristallzüchtung Und Strukturbestimmung Eines Metallorganischen Donator/Akzeptor-Komplexes von I2C=CI2. Zeitschrift für 
Anorg. und Allg. Chemie 2001, 627, 1870-1876. https://doi.org/10.1002/1521-3749(200108)627:8<1870::AID-ZAAC1870>3.0.CO;2 -1 .

(35) Bock, H.; Holl, S. Interaction in Molecular Crystals, 167 [1, 2]. Crystallization and Structure Determination of $\sigma$-Donor/Acceptor Complexes between 1,4-Dioxane and the Polyiodine Molecules I2, I2C=CI2, (IC) $4 \mathrm{~S}$ and (IC)4NR ( $\mathrm{R}=\mathrm{H}, \mathrm{CH} 3$ ). Zeitschrift fur Naturforsch. - Sect. B J. Chem. Sci. 2001, 56, 111-121. https://doi.org/10.1515/znb-2001-0201.

(36) Walsh, R. D. B. Crystal Engineering Through Halogen Bonding; Clemson University, 2001.

(37) Aakeroy, C. B.; Wijethunga, T. K.; Desper, J. Constructing Molecular Polygons Using Halogen Bonding and Bifurcated N-Oxides. CrystEngComm 2014, 16, 28-31. https://doi.org/10.1039/C3CE41887A.

(38) Topić, F.; Puttreddy, R.; Rautiainen, J. M.; Tuononen, H. M.; Rissanen, K.

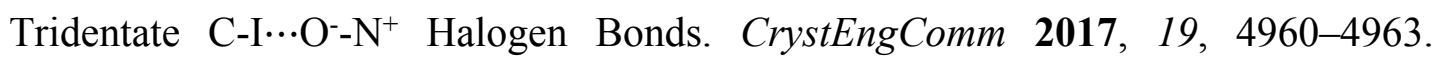
https://doi.org/10.1039/c7ce01381g.

(39) Mugnaini, V.; Punta, C.; Liantonio, R.; Metrangolo, P.; Recupero, F.; Resnati, G.; Pedulli, G. F.; Lucarini, M. Noncovalent Paramagnetic Complexes: Detection of Halogen Bonding in Solution by ESR Spectroscopy. Tetrahedron Lett. 2006, 47, 3265-3269. https://doi.org/http://dx.doi.org/10.1016/j.tetlet.2006.03.033. 
(40) Boubekeur, K.; Syssa-Magalé, J.-L.; Palvadeau, P.; Schöllhorn, B. Self-Assembly of Nitroxide Radicals via Halogen Bonding-Directional NO $\cdots$ I Interactions. Tetrahedron Lett. $\quad \mathbf{2 0 0 6}, \quad 47, \quad 1249-1252$. https://doi.org/http://dx.doi.org/10.1016/j.tetlet.2005.12.088.

(41) Cavallotti, C.; Metrangolo, P.; Meyer, F.; Recupero, F.; Resnati, G. Binding Energies and 19F Nuclear Magnetic Deshielding in Paramagnetic Halogen-Bonded Complexes of TEMPO with Haloperfluorocarbons. J. Phys. Chem. A 2008, 112, 9911-9918. https://doi.org/10.1021/jp803685r.

(42) Wu, W. X.; Wang, H.; Jin, W. J. Pure Organic Hexagonal-Channels Constructed by $\mathrm{C}-\mathrm{I} \cdots-\mathrm{O}-\mathrm{N}+$ Halogen Bond and $\pi-$ Hole $\cdots \pi$ Bond under Mediation of Guest. Cryst. Growth Des. 2018, 18, 6742-6747. https://doi.org/10.1021/acs.cgd.8b01021.

(43) Dahl, J. P.; Avery, J. Local Density Approximations in Quantum Chemistry and Solid State Physics; Springer US, 2013.

(44) Goud, N. R.; Babu, N. J.; Nangia, A. Sulfonamide-Pyridine-N-Oxide Cocrystals. Cryst. Growth Des. 2011, 11, 1930-1939. https://doi.org/10.1021/cg200094x.

(45) Muthuraman, M.; Masse, R.; Nicoud, J.-F.; Desiraju, G. R. Molecular Complexation as a Design Tool in the Crystal Engineering of Noncentrosymmetric Structures. Ideal Orientation of Chromophores Linked by $\mathrm{O}-\mathrm{H} \cdots \mathrm{O}$ and $\mathrm{C}-\mathrm{H} \cdots \mathrm{O}$ Hydrogen Bonds for Nonlinear Optics. Chem. Mater. 2001, 13, 1473-1479. https://doi.org/10.1021/cm000927y. 
(46) Bondi, A. Van Der Waals Volumes and Radii. J. Phys. Chem. 1964, 68, 441-451. https://doi.org/10.1021/j100785a001.

(47) Nguyen, S. T.; Ellington, T. L.; Allen, K. E.; Gorden, J. D.; Rheingold, A. L.; Tschumper, G. S.; Hammer, N. I.; Watkins, D. L. Systematic Experimental and Computational Studies of Substitution and Hybridization Effects in Solid-State Halogen Bonded Assemblies. Cryst. Growth Des. 2018, 18, 3244-3254. https://doi.org/10.1021/acs.cgd.8b00398.

(48) Aakeröy, C. B.; Baldrighi, M.; Desper, J.; Metrangolo, P.; Resnati, G. Supramolecular Hierarchy among Halogen-Bond Donors. Chem. - A Eur. J. 2013, 19, 16240-16247. https://doi.org/10.1002/chem.201302162.

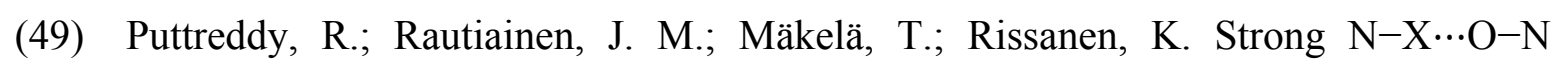
Halogen Bonds: A Comprehensive Study on N-Halosaccharin Pyridine N-Oxide Complexes. Angew. Chemie Int. Ed. 2019, 58, 18610-18618. https://doi.org/10.1002/anie.201909759.

(50) Nizhnik, Y. P.; Sons, A.; Zeller, M.; Rosokha, S. V. Effects of Supramolecular Architecture on Halogen Bonding between Diiodine and Heteroaromatic N-Oxides. Cryst. Growth Des. 2018, 18, 1198-1207. https://doi.org/10.1021/acs.cgd.7b01734.

(51) Clark, T.; Heßelmann, A. The Coulombic $\sigma$-Hole Model Describes Bonding in CX3I‥Y- Complexes Completely. Phys. Chem. Chem. Phys. 2018, 20, 2284922855. https://doi.org/10.1039/C8CP03079K. 
(52) Lommerse, J. P. M.; Stone, A. J.; Taylor, R.; Allen, F. H. The Nature and Geometry of Intermolecular Interactions between Halogens and Oxygen or Nitrogen. J. Am. Chem. Soc. 1996, 118, 3108-3116. https://doi.org/10.1021/ja953281x.

(53) Bader, R. F. W. Atoms in Molecules: A Quantum Theory; International Ser. of Monogr. on Chem; Clarendon Press, 1994.

(54) Wang, P.; Zhao, N.; Tang, Y. Halogen Bonding in the Complexes of CH3I and CCl4 with Oxygen-Containing Halogen-Bond Acceptors. J. Phys. Chem. A 2017, 121, 5045-5055. https://doi.org/10.1021/acs.jpca.7b04342.

(55) Del Bene, J. E.; Alkorta, I.; Elguero, J. Using One Halogen Bond to Change the Nature of a Second Bond in Ternary Complexes with $\mathrm{P} \cdots \mathrm{Cl}$ and $\mathrm{F} \cdots \mathrm{Cl}$ Halogen Bonds. Faraday Discuss. 2017, 203, 29-45. https://doi.org/10.1039/C7FD00048K.

(56) Grabowski, S. J.; Bilewicz, E. Cooperativity Halogen Bonding Effect - Ab Initio

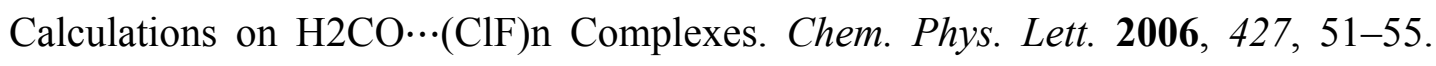
https://doi.org/https://doi.org/10.1016/j.cplett.2006.06.060.

(57) Katritzky, A. R.; Lagowski, J. M. Chemistry of the Heterocyclic N-Oxides; Organic chemistry; Academic Press, 1971.

(58) Frisch, M. J.; Trucks, G. W.; Schlegel, H. B.; Scuseria, G. E.; Robb, M. A.; Cheeseman, J. R.; Scalmani, G.; Barone, V.; Petersson, G. A.; Nakatsuji, H.; Li, X.; Caricato, M.; Marenich, A. V.; Bloino, J.; Janesko, B. G.; Gomperts, R.; Mennucci, 
B.; Hratchian, H. P.; Ortiz, J. V., Izmaylov, A. F.; Sonnenberg, J. L.; Williams-Young, D.; Ding, F.; Lipparini, F.; Egidi, F.; Goings, J.; Peng, B.; Petrone, A.; Henderson, T.; Ranasinghe, D.; Zakrzewski, V. G.; Gao, J.; Rega, N.; Zheng, G.; Liang, W.; Hada, M.; Ehara, M.; Toyota, K.; Fukuda, R.; Hasegawa, J.; Ishida, M.; Nakajima, T.; Honda, Y.; Kitao, O.; Nakai, H.; Vreven, T.; Throssell, K.; Jr., Montgomery, J. A.; Peralta, J. E.; Ogliaro, F.; Bearpark, M. J.; Heyd, J. J.; Brothers, E. N.; Kudin, K. N.; Staroverov, V. N.; Keith, T. A.; Kobayashi, R.; Normand, J.; Raghavachari, K.; Rendell, A. P.; Burant, J. C.; Iyengar, S. S.; Tomasi, J.; Cossi, M.; Millam, J. M.; Klene, M.; Adamo, C.; Cammi, R.; Ochterski, J. W.; Martin, R. L.; Morokuma, K.; Farkas, O.; Foresman, J. B. and Fox, D. J. Gaussian $16\{R\}$ evision $\{C\} .01 .2016$.

(59) Adamo, C.; Barone, V. Toward Reliable Density Functional Methods without Adjustable Parameters: The PBE0 Model. J. Chem. Phys. 1999, 110, 6158-6170. https://doi.org/10.1063/1.478522.

(60) Perdew, J. P.; Ernzerhof, M.; Burke, K. Rationale for Mixing Exact Exchange with Density Functional Approximations. J. Chem. Phys. 1996, 105, 9982-9985. https://doi.org/10.1063/1.472933.

(61) Perdew, J. P.; Burke, K.; Ernzerhof, M. Generalized Gradient Approximation Made Simple. Phys. Rev. Lett. 1996, 77, 3865-3868.

(62) Perdew, J. P.; Burke, K.; Ernzerhof, M. Generalized Gradient Approximation Made 
Simple [Phys. Rev. Lett. 77, 3865 (1996)]. Phys. Rev. Lett. 1997, 78, 1396.

(63) Weigend, F.; Häser, M.; Patzelt, H.; Ahlrichs, R. RI-MP2: Optimized Auxiliary Basis Sets and Demonstration of Efficiency. Chem. Phys. Lett. 1998, 294, 143-152. https://doi.org/http://dx.doi.org/10.1016/S0009-2614(98)00862-8.

(64) Weigend, F.; Ahlrichs, R. Balanced Basis Sets of Split Valence, Triple Zeta Valence and Quadruple Zeta Valence Quality for $\mathrm{H}$ to $\mathrm{Rn}$ : Design and Assessment of Accuracy. Phys. Chem. Chem. Phys. 2005, 7, 3297-3305. https://doi.org/10.1039/B508541A.

(65) Grimme, S.; Ehrlich, S.; Goerigk, L. Effect of the Damping Function in Dispersion Corrected Density Functional Theory. J. Comput. Chem. 2011, 32, 1456-1465. https://doi.org/10.1002/jcc. 21759 .

(66) Boys, S. F.; Bernardi, F. The Calculation of Small Molecular Interactions by the Differences of Separate Total Energies. Some Procedures with Reduced Errors. Mol. Phys. 1970, 19, 553-566. https://doi.org/10.1080/00268977000101561.

(67) Galmés, B.; Franconetti, A.; Frontera, A. Nitropyridine-1-Oxides as Excellent $\pi$-Hole Donors: Interplay between $\sigma$-Hole (Halogen, Hydrogen, Triel, and Coordination Bonds) and $\pi$-Hole Interactions. International Journal of Molecular Sciences . 2019, 20, 3440. https://doi.org/10.3390/ijms20143440.

(68) T. A. Keith, AIMAll (Version 19.02.13); TK Gristmill Software: Overland Park, KS, USA, 2017 (Available via the Internet at Aim.Tkgristmill.Com). 
FOR TABLE OF CONTENTS ONLY

\section{The C-I...- $\mathrm{O}-\mathrm{N}^{+}$Halogen Bonds with}

\section{Tetraiodoethylene and Aromatic $\mathrm{N}$-oxides}

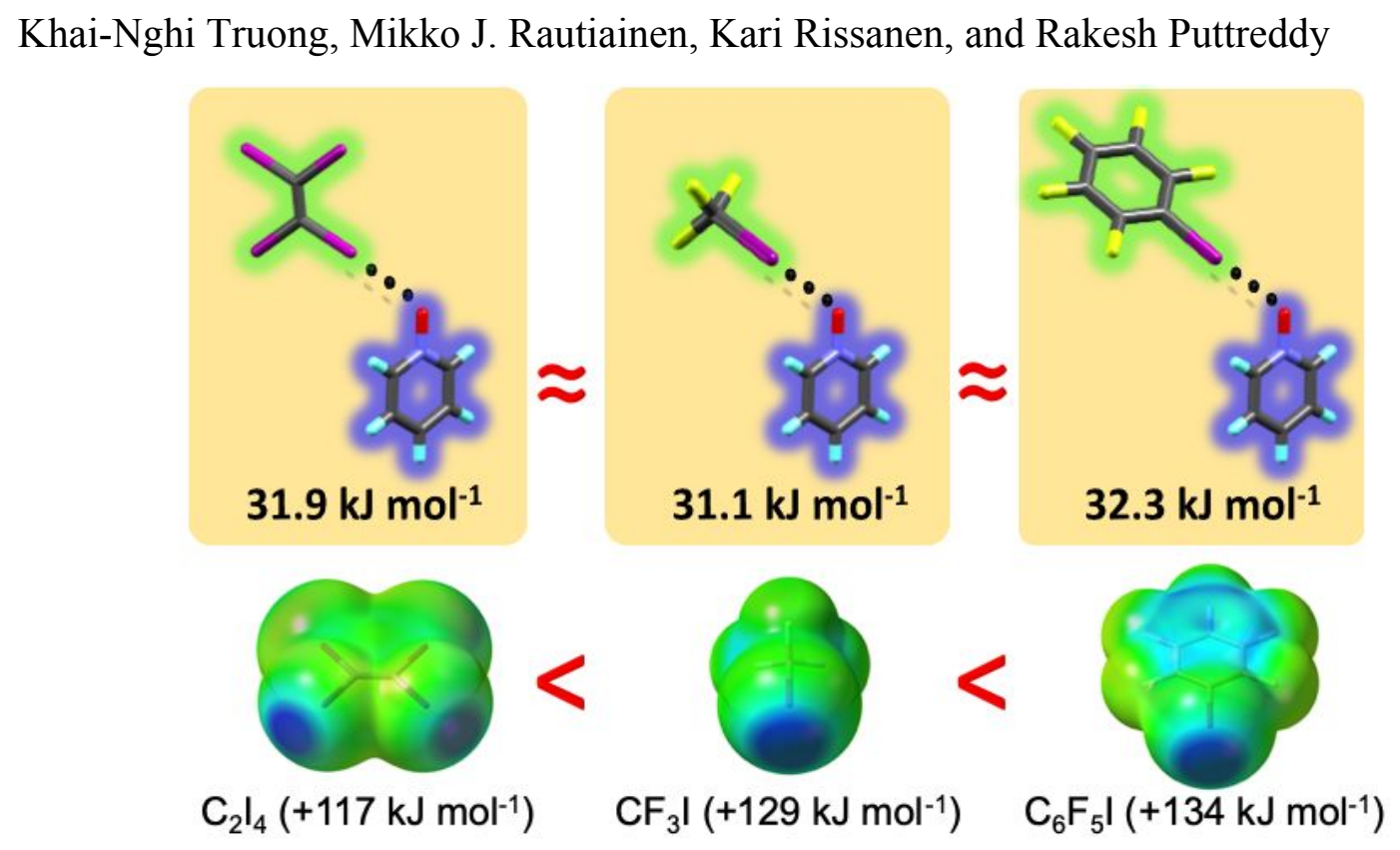

Non-fluorinated $\mathrm{C}_{2} \mathrm{I}_{4}$ and thirteen aromatic $N$-oxides demonstrate $\mathrm{C}-\mathrm{I} \cdots{ }^{-} \mathrm{O}-\mathrm{N}^{+}$bond lengths, and DFT calculated monodentate halogen bonding energies, that are in the range of complexes formed by perfluorohaloalkanes/-arenes and $\mathrm{N}$-oxides. The $\mathrm{C}_{2} \mathrm{I}_{4}$ donor can be ideal candidate as an alternative to well-known perfluorohaloalkanes/-arenes to define the inherent characteristics of halogen bonds by avoiding unnecessary aggregation interactions. 